\title{
The legitimacy of the European human rights regime - a view from the United Kingdom
}

TAMAS GYORFI

School of Law, University of Aberdeen, Taylor Building, AB24 3UB, United Kingdom

\section{Email: t.gyorfi@abdn.ac.uk}

\begin{abstract}
The purpose of the present paper is threefold. First, my ambition is to improve the analytical framework that is used to assess the legitimacy of the European Court of Human Rights. The Court's authority can neither be established nor refuted by a single master-argument. Instead, what we need is a careful balancing exercise and this piece aims to set out the main elements of the justificatory equation. Second, using this framework, I intend to put forward the outline of a coherent critique of the European human rights regime. Third, I hope that my paper is able to shed light on why it is natural to expect more vocal criticism from the United Kingdom than from most other member states of the Council of Europe.
\end{abstract}

Keywords: European Court of Human Rights; Human Rights Act 1998; legitimacy; margin of appreciation; subsidiarity

\section{Introduction}

'If we want things to stay as they are, things will have to change'. The bon mot from Giuseppe di Lampedusa's roman, The Leopard, is often quoted today in relation to Europe's current challenges. After the Brexit referendum, it is now a widely shared opinion that the European Union needs a new vision. This new vision requires the reopening of the debate about the proper relationship between nation states and international organisations. The question is whether there is an appetite for a similar debate about the European human rights regime. Even if many decisions of the European Court of Human Rights (hereafter the ECtHR, the Strasbourg court, or the Court) are fiercely criticised, the dominant position seems to be that the European human rights regime functions reasonably well. The Court is often called the 'conscience of Europe' and is held in high esteem by commentators. As one of those commentators puts it, the ECtHR is 'the crown jewel of the world's most advanced 
international system for protecting civil and political liberties. ${ }^{\text {' }}$ Although the Izmir

Declaration mentions the need 'to pursue long-term strategic reflections about the future role of the Court' ${ }^{2}$ and the Brighton Declaration devotes a whole section to this issue ${ }^{3}$, these reflections revolve primarily around how the Court can be more effective at what it is already doing, and not around the very foundations of the Court's legitimacy. ${ }^{4}$

However, this does not mean that there are no discordant voices. Most of the critiques that challenge the foundations of the European human rights regime originate within the United Kingdom. As Robert Spano, the Icelandic judge of the ECtHR, says: 'It is true, that the Court has over the years been criticised for "judicial activism", but the charges levelled against the Court in the UK over the past two years have been unprecedented. ${ }^{5}$

According to the manifesto of the governing Conservative party, and despite the UK's current preoccupation with the Brexit process, the current legal framework of human rights protection will be revisited after the UK leaves the European Union.

These critiques are often dismissed out of hand and are rejected as 'lacking substance', ${ }^{6}$ 'misconceived as a matter of principle', ${ }^{7}$ or being 'fantasies. ${ }^{8}$ I share most of the worries of

\footnotetext{
${ }^{1}$ LR Helfer, 'Redesigning the European Court of Human Rights: Embeddedness as a Deep Structural Principle of the European Human Rights Regime' (2008) 19 European Journal of International Law 125, 125.

${ }^{2}$ Izmir Declaration, para 15, adopted at the High Level Conference on the Future of the European Court of Human Rights. Izmir, 2011.

${ }^{3}$ Brighton Declaration, section G, adopted at the High Level Conference on the Future of the European Court of Human Rights, Brighton, 2012.

${ }^{4}$ See also The Brussels Declaration, adopted at the High-level Conference on the Implementation of the European Convention on Human Rights, Our Shared Responsibility, Brussels 2015 and the Copenhagen Declaration, adopted at High Level Conference on Reform of the Convention System, Copenhagen, 2018. The individual justice versus constitutional justice debate does not tackle the issue of legitimacy head on. This debate is extensively discussed in S Greer and L Wildhaber, 'Revisiting the Debate about "constitutionalising" the European Court of Human Rights' (2012) 12 Human Rights Law Review 655. Additionally, the question of how international courts can be more effective is different from the one of why we need them. See LR Helfer and AM Slaughter, 'Toward a Theory of Effective Supranational Adjudication' (1997) 107 Yale Law Journal 273. Nevertheless some commentators argue for reopening the debate on legitimacy. For such an example, see J Christoffersen, 'Individual and Constitutional Justice: Can the Power Balance of Adjudication Be Reversed?' in J Christoffersen and MR Madsen (eds), The European Court of Human Rights between Law and Politics, (OUP, Oxford 2011) 181. 'It is now time to look beyond the horizon and reconsider the power balance between national and international authorities.' Ibid, 181.

${ }^{5}$ R Spano, 'Universality or Diversity of Human Rights?: Strasbourg in the Age of Subsidiarity' (2014) 14 Human Rights Law Review 487. This criticism culminated in the Draft Brighton Declaration that was leaked by the Guardian on 28 February 2012. According to this draft, the Court should override a state's interpretation only if the 'national court clearly erred in its interpretation or application of the Convention rights.'

${ }^{6}$ M O'Boyle, 'The Future of the European Court of Human Rights' (2011) 12 German Law Journal 1862, 1867.

${ }^{7}$ Spano, (n 5) 488.

${ }^{8}$ C Gearty, On Fantasy Island: Britain, Europe, and Human Rights (OUP, Oxford, 2016). Tom Zwart makes the general point that 'the only way in which Court insiders can explain the criticism is to frame it in terms of the ignorance and narrow-mindedness of those who express it.' T Zwart, 'More Human Rights than Court: Why the Legitimacy of the European Court of Human Rights Is in Need of Repair and How It Can Be Done' in S
} 
human rights lawyers about the motives that animate these critiques. I argue, nevertheless, that the critical position has a solid intellectual core that can be detached from those illconceived motivations.

The purpose of the present paper is threefold. First, my ambition is to improve the analytical framework that is used to assess the legitimacy of the Court. ${ }^{9}$ The Court's authority can neither be established nor refuted by a single master-argument. What we need is a careful balancing exercise and this piece aims to set out the main elements of the justificatory equation. ${ }^{10}$ Second, using this framework, I intend to put forward the outline of a coherent critique of the European human rights regime. Third, I hope that my paper is able to shed light on why it is natural to expect more vocal criticism from the United Kingdom than from most other member states of the Council of Europe.

\section{Preliminary points}

The question I will address in this paper is as follows: what kind of justificatory reasons do states have to construct (or remain members of) international human rights regimes that adjudicate and enforce human rights? My aim here is not to offer a causal explanation of why the authority of an international court is perceived to be justified, but to engage with the reasons that are or can be offered as justification. ${ }^{11}$ Although the question of whether a state had good reasons (or would have good reasons today) to join an international human rights system is analytically different from the one of whether it has good reasons to leave the same human rights system, I contend that there is a significant overlap between the arguments that are relevant in the two contexts. In the course of my inquiry, I will set aside three argumentative strategies that are, in my view, inadequate in answering the above question.

First, every sophisticated theory of human rights adjudication must distinguish

\footnotetext{
Flogaitis, T Zwart and J Fraser (eds), The European Court of Human Rights and its discontents: turning criticism into strength (Edward Elgar, London, 2013) 77.

${ }^{9}$ I have elaborated a conceptual framework for assessing the justification of domestic constitutional review in $\mathrm{T}$ Gyorfi, Against the New Constitutionalism (Edward Elgar, Cheltenham, 2016). The present article is, to some extent, the extension of this conceptual framework to international human rights adjudication.

${ }^{10}$ Andreas Føllesdal's balancing approach is perhaps the closest to my position. See A Føllesdal, 'Subsidiarity and International Human-Rights Courts: Respecting Self-Governance and Protecting Human Rights-Or Neither?' (2016) 79 Law \& Contemporary Problems 147. However, by balancing similar considerations, we end up with very different conclusions. See also A Føllesdal, 'The Legitimacy of International Human Rights Review: The Case of the European Court of Human Rights' (2009) 40 Journal of Social Philosophy 595; A Føllesdal, 'The Legitimacy Deficits of the Human Rights Judiciary: Elements and Implications of a Normative Theory' (2013) 14 Theoretical Inquiries in Law 339.

${ }^{11}$ As to the empirical or de facto legitimacy of international courts, see LR Helfer and KJ Alter, 'Legitimacy and Lawmaking: A Tale of Three International Courts' (2013) 14 Theoretical Inquiries in Law 479.
} 
between political principles and political institutions. My contention is that all attempts that focus only on the general importance of or general commitment to human rights are doomed to fail since the question at hand is primarily an institutional one. A general commitment to human rights is unable to settle the institutional question of how human rights should be adjudicated and enforced. The flip side of this point is that challenging the European human rights regime cannot be conflated with the criticism of human rights as such. The proponents of the institutional status quo cannot vindicate the moral high ground for themselves and cannot claim that they are the only ones who take human rights seriously.

Second, the justification of human rights regimes is significantly different from the justification of other forms of international cooperation. There are certain goods that, by their very nature, can be produced only at a transnational level. As the Brexit referendum shows, different countries might assign different weight to the value of being a member of the European single market. However, if a country values the membership in such a cooperation, it cannot create such a market alone. Creating a single market requires, by definition, the cooperation of more countries. By contrast, the protection of human rights does not necessarily require such a collective action. It follows from the above distinction that one can have different views on the different forms of international cooperation. One can be, for instance, an ardent advocate of the European single market (and what it entails) and, at the same time, be a critic of the European human rights regime. To summarise the previous two points, the critical position presupposes neither rights-scepticism nor Euroscepticism.

Third, my argument is based on the assumption that human rights have very often more than one reasonable interpretation. Even if each right has an uncontroversial core meaning, my contention is that the cases that the ECtHR finds admissible and originate from stable democracies typically do not belong to this category. The existence of reasonable rights disagreements implies that an adequate justificatory theory cannot rely on the outcome of particular decisions as the criterion of institutional legitimacy. It is a non-starter to argue that the ECtHR got it right in case $x$ and that it made a decision that is superior to the one that was delivered by a domestic court. Although outcome-related considerations should play an important role in the justificatory discourse, these considerations must be relatively general and focus on the epistemological and motivational features of institutions rather than the outcome of particular decisions. This restriction on the eligible justificatory arguments has far-reaching methodological implications - a few of them are worth emphasising here.

The debate about the legitimacy of the European human rights regime is dominated by human rights lawyers (including the judges of the Court) whose primary expertise is on 
doctrinal issues and whose research focuses on the jurisprudence of the Strasbourg court. However, if an adequate justificatory theory must centre around general institutional considerations rather than around the evaluation of particular decisions, then this expertise on doctrinal issues can play only a limited role in the justificatory debate. Assessing the epistemological performance of an institution and the motivations of its members is not a matter of doctrinal expertise.

My argument also aims to demonstrate that many of the relevant justificatory considerations are empirical in nature. Whether a state has good reasons to confer authority on an international human rights court depends both on the robustness of its own political institutions and the extent to which it can influence other states. As Goodman and Jinks state, 'regime design choices in international law turn on empirical claims about how states behave and under what conditions their behaviour changes. ${ }^{12}$ I claim that these empirical considerations do not only provide the political context for the justification of the European human rights regime but are an integral part of the justificatory exercise.

Within the confines of this article, it is impossible to support my argument with sufficiently nuanced empirical analysis. However, I hope that even my sketchy empirical observations are able to establish the claim that the justification of the European human rights regime is contextual. The strength of the relevant arguments and the balance thereof can change over time. Perhaps more importantly, the strength of the proffered arguments might also vary from country to country. Different countries do not only perceive the justification of the present international human rights framework differently, but they indeed have different reasons to endorse the authority of the ECtHR.

\section{The argument from sovereignty}

In a short paper supporting the role of the Strasbourg court, Letsas argues that 'there is no objection to be made against the legitimacy of the Strasbourg Court that cannot equally be made against the UK Supreme Court. ${ }^{13}$ It is beyond the scope of the present paper to address the justifiability of domestic constitutional review. However, I contend that even if domestic constitutional review is justified, it does not automatically follow that transnational human rights review is also justified, since there is an important difference between domestic and

\footnotetext{
${ }^{12}$ R Goodman and D Jinks, 'How to Influence States: Socialization and International Human Rights Law' (2004) 54 Duke Law Journal 621, 622.

13 G Letsas, 'In Defense of the European Court of Human Rights' available at: <http://www.heritagescience.ac.uk/human-rights/news/documents/prisoners-vote.pdf>
} 
international courts.

The institutions of a state, including its courts, act on behalf of a political community that is considered the ultimate source of political authority within the boundaries of that state. When a government confers authority on an international organisation, it gives up part of its own authority and transfers some decisions from the political community to international institutions. We do not expect and cannot demand states to give up part of their authority without justification. In other words, there is a prima facie reason against such a transfer of authority. The asymmetry between domestic and international courts can be explained away only by challenging the right of a political community to govern itself and assume that the authority of international courts is independent of sovereign states.

My argument is predicated on the assumptions that (1) there is no European wide demos that could be considered the location of final political authority in Europe ${ }^{14}$ (2) Even if there were such a demos, it is not coextensive with the citizenry of the member states of the Council of Europe; (3) If the European political order is understood as a demoi-cracy where separate peoples jointly exercise political authority, then 'No liberal democratic People is incorporated into a political order and subjected to constitutional rules against the approval of its constitutive power.' 15

Claiming that the transfer of a state's authority requires justification, however, does not lead us very far. States routinely give up part of their authority for various reasons. 'Taking back control' is valid, but, on its own, not a particularly strong argument. To understand the justificatory equation that is relevant in the specific context, we must clarify both the cost of and the justifications for transferring part of a state's authority to international human rights courts. The present section focuses on the 'sovereignty cost' 16 of such a transfer of authority and the following subsections will scrutinise the justification for such a move.

The sovereignty cost of a human rights regime depends on many factors, including how the international court in question can be accessed, what types of remedies the court can provide, how robust the scrutiny of the court is and how much weight national courts give to

\footnotetext{
14 This does not imply the claim that there is no European public sphere or that some elements of a Europeanwide political community do not exist.

${ }^{15}$ F Cheneval, S Lavenex and F Schimmelfennig, 'Demoi-cracy in the European Union: Principles, Institutions, Policies' (2015) 22 Journal of European Public Policy 1, 4.

${ }^{16}$ I borrow the term from A Moravcsik, 'The Origins of Human Rights Regimes: Democratic Delegation in Postwar Europe’ (2000) 54 International Organization 217, 227.
} 
the jurisprudence of the international court in question.

As is well-known, in the first years of its existence, the ECtHR did not seem to develop into a high-profile institution, and the expectation was that its operation would not really affect mature democracies. ${ }^{17}$ To put it in the terminology of the present article, the sovereignty costs of the regime were perceived to be marginal. This was probably a decisive consideration for many countries, including the United Kingdom, that allowed them to accept the jurisdiction of the court and the right of individual petition. ${ }^{18}$ Today, due partly to the changing attitude of the Court and partly to the member states' own decisions, the situation is fundamentally different. The ECtHR is often characterised as the de facto constitutional court of Europe. ${ }^{19}$ Although this description is a bit vague, with proper qualifications it can serve as a useful shorthand to characterise the position of the Strasbourg court. Let me spell out, therefore, what I mean here by de facto constitutional court.

The ECHR enshrines human rights most of which are also protected by national constitutions. Even if the textual formulations of the two sets of rights are often different, this dual framework creates a potential conflict: there can be a discrepancy between the interpretation of domestic courts and that of the ECtHR. ${ }^{20}$

In a municipal legal system, such conflicts are most often handled by rules that create a clear hierarchy between the conflicting interpretations. In most countries, there are no similar formal rules that would neatly handle the potential conflict between the conflicting interpretations of domestic and international courts. ${ }^{21}$ As Nico Krisch explains, there is not a neat legal hierarchy between the rival interpretations of overlapping rights: 'We find different norms and actors competing for ultimate authority; and since they lack a common legal frame of reference, they compete, to a large extent, through politics rather than legal argument. ${ }^{22}$

A lot has been written recently about the precise nature of the relationship between domestic courts and the ECtHR. ${ }^{23}$ I cannot do justice to the complexity of this question

\footnotetext{
${ }^{17}$ MR Madsen, 'The Challenging Authority of the European Court of Human Rights: From Cold War Legal Diplomacy to the Brighton Declaration and Backlash' (2016) 79 Law \& Contemporary Problems 141, 145.

18 Ibid, 151.

${ }^{19}$ Ibid, 166.

${ }^{20} \mathrm{G}$ Luebbe-Wolff, 'Who Has the Last Word? National and Transnational Courts—Conflict and Cooperation' (2011) 30 Yearbook of European Law 86, 87-8.

${ }^{21}$ But see, for instance, Art. 94 of the Dutch Constitution that declares that treaty provisions override conflicting national statutes.

${ }^{22}$ N Krisch, 'The Open Architecture of European Human Rights Law' (2008) 71 The Modern Law Review 183, 184.

${ }^{23}$ E Bjorge, Domestic Application of the ECHR: Courts as Faithful Trustees (OUP, Oxford, 2015); J Gerards
} 
within this article, and so will paint with a broad brush here. However, I submit that, as a crude generalisation, we can say that the Strasbourg court does not simply interpret an international human rights treaty, but also determines the meaning of domestic constitutional rights when there is an overlap between a domestic constitution and the ECHR.

This is more straightforward in those countries where Convention rights themselves have constitutional status. The Austrian constitution of 1945, for instance, did not have a modern bill of rights and therefore the ECHR was elevated to constitutional status in $1964 .^{24}$ The United Kingdom also lacked a comprehensive bill of rights before the Human Rights Act 1998 (hereafter HRA) was enacted. As is well known, the HRA does not lay down a new list of fundamental rights but incorporates Convention rights into domestic law.

But even in those countries where domestic constitutional rights have their own textual identity and the domestic constitution is of higher rank than the statute that incorporates the Convention, the jurisprudence of the ECtHR has an immense influence on domestic constitutional law. Constitutional review bodies tend to, but more importantly are required to interpret the rights enshrined in domestic constitutions taking into consideration Strasbourg case law. In some countries, like Spain and Portugal, there is an explicit constitutional requirement to interpret constitutional rights in light of the analogous provisions of international law. ${ }^{25}$ In other countries, the doctrine of convention-friendly constitutional interpretation of domestic constitutional rights was developed by constitutional courts. $^{26}$

My claim about the role of the Strasbourg court in determining the content of domestic constitutional rights is a qualified one. There are at least three qualifications: (1) When the Strasbourg case law is not settled, domestic courts can engage in a dialogue with the Court and play a proactive role in shaping its jurisprudence. ${ }^{27}$ (2) In other cases, the

\footnotetext{
and J Fleuren (eds), Implementation of the European Convention on Human Rights and of the Judgments of the Ecthr in National Case Law: A Comparative Analysis (Intersentia, Cambridge/Antwerp/Portland 2014).

${ }^{24}$ Art. 149 (1) of the Austrian constitution refers back to the general rights of nationals enshrined in the Basic Law of 21 December 1867.

${ }^{25}$ Constitution of Spain, Art. 10 (2); Constitution of Portugal, Art. 16 (2).

${ }^{26}$ As the Görgülü decision of the German Constitutional Court (FCC) states, 'the guarantees of the Convention influence the interpretation of the fundamental rights and constitutional principles of the Basic Law. The text of the Convention and the case-law of the European Court of Human Rights serve, on the level of constitutional law, as guides to interpretation in determining the content and scope of fundamental rights and constitutional principles of the Basic Law, provided that this does not lead to a restriction or reduction of protection of the individual's fundamental rights under the Basic Law - and this the Convention itself does not desire.' 111 $B V \operatorname{erfGE} 307,317$. In a later decision, the FCC seems to give even stronger status to the jurisprudence of the Strasbourg court. 128 BVerfGE, 326, 370-371.

${ }^{27}$ E Bjorge, 'National Supreme Courts and the Development of ECHR Rights' (2011) 9 International Journal
} 
doctrine of the margin of appreciation confers the authority of determining what Conventionrights mean on domestic institutions. (3) Even when there is settled case law, many domestic courts have elaborated on the limits of their loyalty to the Strasbourg court.

In the United Kingdom, for instance, the Supreme Court vindicated the right to deviate from Strasbourg jurisprudence if the Strasbourg court misunderstood domestic law or following Strasbourg case law would be inconsistent with some fundamental constitutional principles of the United Kingdom. ${ }^{28}$ Similarly, the Görgülü decision of the Federal Constitutional Court of Germany (FCC) sets limits on the FCC's loyalty to Strasbourg. ${ }^{29}$ However, the fact that this loyalty has limits is compatible with the general principle that within these limits domestic courts follow and are required to follow the jurisprudence of the ECtHR even if they disagree with the content of a decision. ${ }^{30}$ Although Lord Roger's famous dictum 'Argentoratum locutum: iudicium finitum - Strasbourg has spoken, the case is closed ${ }^{31}$ must be qualified, it captures well what I call here the general rule.

I will treat the claim that the ECtHR is the de facto constitutional court of Europe as a shorthand for this qualified primacy of Strasbourg jurisprudence over domestic human rights decisions. Although domestic courts remain the final authorities on the interpretation of domestic constitutional rights, this final authority is compatible with the qualified primacy they attribute to the decisions of the ECtHR in the interpretation of those rights. Therefore, when we assess the legitimacy of the present European human rights regime, the question is not simply why states construct international human rights courts in general, but why they make the ECtHR the final arbiter of their domestic constitutional rights.

Human rights do not provide us with algorithms that mechanically decode the meaning of legal provisions; in order to apply these provisions to particular situations, we have to inject meaning into these abstract provisions. Choosing one particular conception of an abstract concept instead of another will inevitably reflect the moral outlook of the interpreter. ${ }^{32}$ Defining the more precise meaning of human dignity, equality, privacy or freedom is not a

\footnotetext{
of Constitutional Law 5.

${ }^{28} R$ v Horncastle [2009] UKSC 14, [2010] 2 AC 373, para 11; Manchester City Council v Pinnock [2010] UKSC 45, [2011] 2 AC 104, para 48.

29111 BVerfGE, 307, 319. See also Luebbe-Wolff (n 20) 87; F Hoffmeister, 'Germany: Status of European Convention on Human Rights in Domestic Law' (2006) 4 International Journal of Constitutional Law 722, 729.

${ }^{30}$ See, for instance, 120 BVerfGE, 180 (Caroline III) or $R$ (on the application of Chester) $v$ Secretary of State for Justice [2013] UKSC 63, [2014] A.C. 271.

31 Secretary of the State for the Home Department v AF (No3) [2009] UKHL 28, [2010] 2 AC 269, para 98.

32 Dworkin, Freedom's Law: The Moral Reading of the American Constitution (Harvard University Press, Cambridge MA, 1996) 1-38.
} 
trivial matter but is among the most significant moral decisions a political community can make. Transferring these decisions to an international court incurs significant costs on a political community and, therefore, such a transfer of authority requires robust justification.

I have argued above that at present there is only a nascent European political community and this political community cannot be considered as the ultimate source of political authority. It should be noted, however, that the governments and the citizens of different European states have different attitudes towards the emergence of a European demos. Although this question is most often raised in the context of the EU, and the EU and the ECHR are legally distinct entities, a country's general stand on a European demos also shapes its attitude toward the ECHR. One factor that explains why the UK is more critical of the European human rights regime than other countries is that the idea of an overarching European demos has always been glaringly unattractive in the UK. Even before the Brexit referendum, David Cameron, then the Prime Minister of the UK, negotiated a deal with the EU that exempted the UK from the principle of an 'ever closer union'.

\section{Epistemic considerations}

Although transferring a part of a state's authority to an international human rights court has considerable costs in terms of sovereignty, the benefits of such a transfer might compensate for that loss. An international court might be better suited or better motivated to protect human rights than national courts. I will turn first to the question of whether international courts have an epistemic edge over their national counterparts. I will argue that the exact opposite is true and a combination of epistemic considerations and legitimacy-related concerns gives us strong reasons to prefer national courts over international ones in the specification of human rights. A senior British judge, Lord Hoffmann, argued that: 'If one accepts, as I have so far argued, that human rights are universal in abstraction but national in application, it is not easy to see how in principle an international court was going to perform this function of deciding individual cases, still less why the Strasbourg Court was thought a suitable body to do so.'33

I believe that Lord Hoffmann touches upon an important point in his lecture but his conceptual framework is not nuanced enough to handle the issue properly. Although it seems to me that the main thrust of his argument is correct, I aim to strengthen the argument by

\footnotetext{
${ }^{33}$ Lord Hoffmann, 'The Universality of Human Rights' (2009) 125 Law Quarterly Review 416, 422.
} 
recasting it in a different conceptual framework.

First of all, I submit that the term 'application' is too vague for our present purposes. When applying abstract human rights provisions to particular cases, there are usually many premises in the argument that mediate between the abstract human rights provision and the facts of the case. To put it differently, judges are required to choose one of the rival interpretations or conceptions of abstract human rights provisions, that is to say, they are required to specify or articulate the meaning of the said rights before they can apply them to the facts of the case. ${ }^{34}$ For instance, when the Court asserts that the decision about our own death is within the scope of the right to private life, this premise mediates between the abstract right and the facts of the case, but this specification itself does not require the intimate knowledge of the latter. ${ }^{35}$

Lord Hoffmann is right to argue that when applying general norms to particular fact situations, a domestic court usually has a more intimate knowledge of the factual circumstances than an international court and in those cases, the former has an epistemic edge over the latter. This insight is part of the jurisprudence of the Strasbourg court and is acknowledged by the doctrines of subsidiarity and the margin of appreciation. However, this leaves open the more interesting question of whether domestic courts should also have preeminence in the specification of abstract human rights. The better understanding of the facts of particular cases does not justify that they should have pre-eminence in the process of specification, but this is exactly what I will argue for here.

The starting point of my argument is that our views on and attitudes to the adjudication of human rights are informed and shaped by two fundamentally different positions on moral epistemology, that I will call the Enlightenment View of Reason and Reasonable Pluralism, respectively.

The proponents of what Gaus calls the Enlightenment View of Reason believe that reasonable people will converge on true propositions since they all share the capacity of reason, and the norms of good reasoning are the same for everyone. ${ }^{36}$ So even if we disagree, for instance on the legality of assisted suicide, one of the rival positions on the issue is objectively correct and the other positions are incorrect and, therefore, unjustified.

\footnotetext{
${ }^{34}$ W Sadurski, 'Rights and Moral Reasoning: An Unstated assumption-A Comment on Jeremy Waldron's "Judges as Moral Reasoners"' (2009) 7 International Journal of Constitutional Law 25, 27.

35 Pretty v the United Kingdom, Application No 2346/02, Merits, 29 April 2002, para 67.

${ }^{36}$ GF Gaus, Contemporary Theories of Liberalism: Public Reason as a Post-Enlightenment Project (Sage, London, 2003) 3.
} 
The idea of Reasonable Pluralism does not challenge the possibility of objectively true moral propositions; it puts forward a claim not about their truth but about their justifiability. ${ }^{37}$ Its central tenet is that even if there are moral propositions that can be justified to each person, on most complex moral issues people will reasonably hold different views. ${ }^{38}$ $A$ will be justified in holding $p$ while $B$ will be justified in holding non- $p$. If that is the case, both $p$ and non- $p$ are inconclusively justified. ${ }^{39}$

As there seems to be a tension between the idea of Reasonable Pluralism and the universality of human rights, it is important to clarify their relationship here. When people claim that human rights are universal, they often endorse two distinct theses about human rights. (1) When someone claims that $A$ has a human right to $x$, she makes a claim about the scope and the preconditions of the said right. Every human being, so the argument runs, has the right to $x$ by virtue of being human, regardless of their membership in any political community or their personal qualities and circumstances. This is a substantive moral claim about the scope of human rights and not an epistemological one. The substantive claim may or may not be supported by universally justified reasons. In addition, many advocates of human rights also endorse the epistemic claim that (2) human rights are universally justified and that no reasonable person can reject such claims.

The idea of Reasonable Pluralism is an epistemic position and as such is agnostic on (but is compatible with) the thesis of universal scope. It is also compatible with the idea that some human rights claims are universally justifiable. However, the proponents of this position hold that the specification of human rights is very often subject to reasonable disagreement and we cannot expect even in the long run that such disagreements will disappear. To use computer parlance, reasonable disagreement is not a bug, but a feature of the human condition.

Since the text of human rights documents do not impose sufficiently strong limits on the discretion of judges and they themselves often revolve around complex moral issues, the interpretation of human rights (both determining the scope of those rights and balancing them

\footnotetext{
37 The distinction between the Enlightenment View of Reason and Reasonable Pluralism is, therefore, fundamentally different from the distinction between universalism and relativism. For an overview of the universalism versus relativism debate in the context of human rights, see DL Donoho, 'Autonomy, SelfGovernance, and the Margin of Appreciation: Developing a Jurisprudence of Diversity Within Universal Human Rights' (2001) 15 Emory International Law Review 391. For reasons explained below, it is simply wrong to argue that the margin of appreciation doctrine assumes moral relativism. For such an argument, see E Benvenisti, 'Margin of Appreciation, Consensus, and Universal Standards' (1998) 31 New York University Journal of International Law and Politics 843, 844.

38 J Rawls, Political Liberalism (Columbia University Press, New York, 1993) 54-8.

${ }^{39}$ Gaus (n 36) 14.
} 
against the public interest) is also subject to reasonable disagreements. The questions of how freedom of expression should be balanced against the right to private life, or whether the right to private life encompasses the right to decide how we want to die, or how freedom of religion should be balanced against the prohibition of discrimination, all give rise to reasonable disagreements. However, the term Reasonable Pluralism also implies that not all disagreements are reasonable. This insight also applies to the interpretation of human rights. Human rights might have interpretations that are beyond the range of reasonable alternatives. Although the two positions outlined above say nothing about political institutions, by adding some further premises to the argument, the two views will have far-reaching implications for institutional design: they will lead us to different benchmarks to assess the performance of our institutions. According to the Enlightenment View of Reason, if a judge believes that her position is the true one, she also has good reasons to believe that her position is justifiable to everyone else, that is, it is universally justified, irrespective of the actual beliefs others hold. If moral principles are universally justified, an Italian, a Russian and a British judge are in symmetrical positions and have equal access to the universally justified specifications of human rights. In that case, we have no general epistemic reason to prefer domestic courts to international ones or international courts to domestic ones.

By contrast, if one believes that the idea of Reasonable Pluralism is the superior view on moral epistemology, as I do, she must admit that even if she believes $p$ to be true, it does not follow that $p$ is justifiable to everyone. Whether $p$ is justifiable to other people depends on what other beliefs they hold. ${ }^{40}$ If this is correct, it is highly unlikely that judicial decisions meet the criterion of universal justifiability. Even to make a plausible claim to that effect, judges should be able to monitor the belief systems of others. Most often courts, including the Strasbourg court, develop a reasonable but inconclusively justified interpretation of abstract human rights. (And the dissenting judges of the same court often develop another, also reasonable position.) By transferring the authority to specify human rights from national courts to international ones, the reasonable but inconclusively justified views of a domestic court are replaced by those of an international court.

The Enlightenment View of Reason underlies the attitude of many scholars of international institutions. For instance, writing on transnational judicial dialogue, Helfer and Slaughter write: 'Equally important, the resulting decisions can contribute to the development

\footnotetext{
${ }^{40}$ However, a belief that is justifiable in $A$ 's belief system is not neccessarily the one that is presently held by $A$.
} 
of a genuinely transnational or supranational body of law: a set of principles informed by and building on one another, textually and culturally differentiated as necessary but acknowledging the promise of universality. ${ }^{41}$

From the perspective of the Enlightenment View of Reason, uniformity has an inherent value. (I assume that the value of convergence or harmonisation is parasitic on the value of uniformity.) From the perspective of Reasonable Pluralism, the uniform specification of abstract human rights is not only unfeasible but also undesirable, even as a distant ideal. Since the 'free exercise of free human reason' ${ }^{42}$ will inevitably give rise to different views on the desirable specification of human rights, instead of pursuing the promise of universality (as uniformity), we should focus on the fair method of selecting someone's inconclusively justified views when a choice has to be made. If that is the case, the question becomes why a political community should elevate the reasonable but inconclusively justified views of an international court on the meaning of human rights to authoritative status within its own jurisdiction.

I will argue that there are at least two important reasons against this practice. First, even if a moral principle cannot be universally justified, it might be justified to each member of a bounded political community. I will call the principles that satisfy this criterion publicly justified principles. I will also assume that within that bounded political community, a publicly justified interpretation of a human right is preferable to one that is justified only to one segment of the community. But even if none of the interpretations of an abstract right can actually be publicly justified, the court must at least be able to track publicly justified principles. ${ }^{43}$ The judges of domestic courts are in a better position to assess what is justified within the belief systems of their fellow citizens. It would be absurd to claim, for instance, that a Russian judge would be particularly well-suited to assess which principles are justified in the belief systems of British citizens and vice versa.

Second, even if a human right does not have a publicly justified interpretation within a political community, it is important that a wide range of the reasonable interpretations that are prevalent in that community be fairly represented in the decision-making process. An international court cannot plausibly claim that it reflects the reasonable views that are prevalent in the said community. Although it might be the case that domestic courts also track

\footnotetext{
${ }^{41}$ Helfer and Slaughter (n 4) 368. For a similar position, see Benvenisti (n 37) 843.

42 Rawls (n 38) 144.

${ }^{43}$ For a detailed justification of this requirement, see GF Gaus, Justificatory Liberalism: An Essay on Epistemology and Political Theory (OUP, Oxford, 1996) 215-45.
} 
publicly justified principles very imperfectly and represent the prevalent views of their respective communities poorly, all that matters in the present context is their comparative advantage over international courts.

At this point, it could be objected that (1) giving pre-eminence to domestic courts in the specification of human rights is likely to make their jurisprudence parochial and (2) it also shields domestic practices from international criticism. As to the first objection, there is a huge difference between making uniformity a regulative ideal and broadening the pool of arguments by disseminating information and sharing good practices on human rights issues. Broadening the pool of relevant arguments requires neither the uniform specification of human rights nor an international court with the final authority to determine the meaning of such rights.

As many scholars have pointed out, today the judges of constitutional courts engage in a global dialogue. ${ }^{44} \mathrm{~A}$ court might choose not to participate in this dialogue, but the dialogue is open to all. The Canadian Supreme Court, the High Court of Israel, or the South African Constitutional Court, to name a few, are respected institutions within the 'community of courts' and although they work in a different international context than their European counterparts, their practice is certainly not parochial. ${ }^{45}$

As to the second objection, my position is against imposing a uniform specification of human rights on states when human rights have more than one reasonable interpretation (this can be called the fine-tuning of human rights). However, as the name Reasonable Pluralism suggests, not all disagreements are reasonable. The position I defend has the critical potential to challenge those practices that are beyond the range of reasonable alternatives - policing the boundaries of reasonableness is compatible with my suggestion. However, when we translate the above principles to institutional design, we indeed face a dilemma. If we give too much power to an international court, different political communities cannot pursue their own interpretation of human rights. If we give too much leeway to states, they can get away even

\footnotetext{
${ }^{44}$ AM Slaughter, 'A Global Community of Courts' (2003) 44 Harvard International Law Journal 191; T Groppi and M Ponthoreau (eds), The Use of Foreign Precedents by Constitutional Judges (Hart, Oxford/Portland, Oregon, 2013).

${ }^{45}$ The UK Supreme Court (and its predecessor, the House of Lords) has also been referring to foreign law extensively. See T Gyorfi, 'The Supreme Court (House of Lords) of the United Kingdom,' in A Jakab, A Dyevre and G Itzcovich (eds), Comparative Constitutional Reasoning (CUP, Cambridge, 2017) 679-722.Richard Clayton makes the interesting point that since the HRA came into force, the highest court of the UK pays less attention to Commonwealth jurisdictions. R Clayton, 'Should the English Courts under the HRA Mirror the Strasbourg Case Law?' in KS Ziegler, E Wicks and L Hodson (eds), The UK and European Human Rights: A Strained Relationship? (Hart, Oxford/Portland, Oregon, 2015) 107-8. If that is true, UK judges have not become more cosmopolitan, but have simply reoriented their comparative approach.
} 
with manifestly unreasonable interpretations of human rights. My contention here is that this institutional dilemma does not have a universal solution. We can err in both directions and the optimal choice between the two alternatives will depend primarily on the shape of the political system.

Others might object that although they find my argument compelling, all that is said here is already accounted for by the doctrines of the margin of appreciation and subsidiarity. ${ }^{46}$ As many commentators have observed, in recent years, the Court has followed an increasingly deferential approach that often focuses on the procedural aspect of national decision-making instead of the substantive correctness of the decision. ${ }^{47}$ In the recent Copenhagen Declaration, the Committee of Ministers has put even greater emphasis on the freedom of domestic courts in the balancing process. ${ }^{48}$ Robert Spano goes so far as claiming that the 'age of subsidiarity' has arrived. ${ }^{49}$ I find this objection unconvincing for two reasons. First, my argument does not simply restate the need for a margin of appreciation but gives more determinate content to it. The doctrine of the margin of appreciation is compatible with both the Enlightenment View of Reason and the idea of Reasonable Pluralism. However, the two positions interpret the role of the doctrine very differently.

According to the Enlightenment View of Reason, the margin of appreciation is justified only in those cases when domestic institutions are more likely to have intimate knowledge of certain facts but there is no reason to defer to domestic courts in the specification of human rights in general. By contrast, the idea of Reasonable Pluralism, combined with some plausible premises about legitimacy, suggests that domestic courts should play a preeminent role in the specification of human rights in general because they can track better those interpretations of human rights provisions that are publicly justified in their own political community, and they are also more likely to give fair representation to those interpretations that are prevalent in their own society.

Second, although the question of whether a certain interpretation remains within the range of reasonable alternatives itself is open to contestation, it is implausible to claim that the Strasbourg court's activity is limited to policing the boundaries of reasonableness. Even the judges of the Strasbourg court admit that there is no consensus among them on the precise

\footnotetext{
${ }^{46}$ Spano (n 5) 492.

${ }^{47}$ For a summary of this new approach, see Gerards and Fleuren (n 23) 52-71.

48 Copenhagen Declaration, adopted at High Level Conference on Reform of the Convention System, Copenhagen, 2018, $28 \mathrm{c}$.

${ }^{49}$ Spano (n 5).
} 
scope of the margin of appreciation and some judges strongly oppose the doctrine. ${ }^{50}$

More importantly, in many of the landmarks decisions of the Court, where there was a disagreement between the judges of domestic courts and those of the Strasbourg court, or within the Strasbourg court itself, the outvoted position could hardly be considered as manifestly unreasonable. A recent study analyses the reasoning process of the Strasbourg court in forty of its landmark decisions, 28 of which cases contained at least one dissenting opinion. ${ }^{51}$ The presence of dissenting opinions suggests (but not proves) that in all these cases there were reasonable arguments on both sides of the debate. In line with the thrust of my argument, some commentators explicitly acknowledge that one important function of the Court is fine-tuning, that is, choosing the optimal specification of human rights. ${ }^{52}$ Although the Court's recent emphasis on procedural review should be applauded, I believe that the jury is still out whether this approach will be consistently pursued. In addition, even the most relevant provision of the recent Copenhagen Declaration (28.c) that accommodates furthest reasonable rights disagreement, focuses very much on how human rights should be balanced against the public interest when applying Articles 8-11 of the ECHR. Reasonable disagreement, however, is not limited to the balancing stage of human rights arguments but also applies to how the scope of human rights (including but not limited to Article 8-11 of the ECHR) is defined.

\section{Reasonable disagreement and weak judicial review}

The idea of Reasonable Pluralism, combined with some plausible assumptions about political legitimacy, provides us with a general argument for the pre-eminence of domestic courts in the specification of human rights. However, this general argument is further accentuated in jurisdictions in which the institutional design of constitutional review itself reflects that human rights may have more than one reasonable interpretation.

As is well known to comparative constitutional lawyers, the Commonwealth model of judicial review has established a mechanism of human rights protection in which the legislature can disregard or override a court's determination of what a human right requires. ${ }^{53}$

\footnotetext{
${ }^{50}$ P Mahoney, 'The Relationship Between the Strasbourg Court and the National Courts - As Seen from Strasbourg' in Ziegler, Wicks and Hodson (n 45) 25.

51 J Gerards, 'The European Court of Human Rights' in Jakab, Dyevre and Itzcovich (n 45).

52 L Wildhaber, 'Rethinking the European Court of Human Rights' in J Christoffersen and MR Madsen (eds), The European Court of Human Rights between Law and Politics, (OUP, Oxford, 2011) 210.

53 S Gardbaum, The New Commonwealth Model of Constitutionalism: Theory and Practice (CUP, Cambridge, 2013) 26-30.
} 
According to section 4(2) of the HRA, for example, a court can issue a declaration of incompatibility if it comes to the conclusion that a piece of primary legislation violates a Convention right. However, such a declaration does not affect the validity of the challenged law.

The very essence of weak judicial review is that it gives the final say on rights disagreements to the legislative body. Subjecting the Commonwealth model of judicial review to the supervision of the ECtHR makes this final say illusory. The final say on what Convention rights require belongs to the Strasbourg court. Although as a matter of domestic public law the UK Parliament can disregard a declaration of incompatibility, the UK has a legal obligation to comply with the decisions of the Strasbourg court. This is probably part of the explanation of why the UK government tends to comply, almost mechanically, with the decisions of domestic courts and why it tends not to exercise its right to the final say. ${ }^{54}$ From a practical point of view, the declaration of incompatibility becomes hardly distinguishable from the strike-down power of strong judicial review, and thereby the system loses its distinctive feature. Whether this is something that one should welcome or regret depends on one's understanding of the role of the declaration of incompatibility.

It can be argued that the way the HRA allocates authority between Parliament and the courts gives Parliament a legal permission to violate human rights but at the same time puts the legislators under pressure to bear the political costs of such an action. ${ }^{55}$ Looking from that perspective, we do not have too much reason to regret that under the supervision of the Strasbourg court, Parliament's final say on human rights issues becomes illusory.

However, in my view, the HRA has a much more attractive interpretation. The alternative interpretation acknowledges that Parliament and the courts are epistemic equals, and both Parliament and the courts are capable of developing reasonable interpretations of human rights. According to this interpretation, a declaration of incompatibility is not a straightforward failure of the government but rather the indication of a rights disagreement. Parliament's legal right not to act upon a declaration of incompatibility should not be conceptualised as a legal permission to violate human rights, but as Parliament's right to stick to its own interpretation of a human right in the face of a rights disagreement.

This is in stark contrast with the approach of most European legal systems where it is assumed that the specification of human rights is the monopoly of the judiciary. Rackow's

\footnotetext{
${ }^{54}$ Kavanagh, 'What's so Weak about "Weak-Form Review"? The Case of the UK Human Rights Act 1998' (2015) 13 International Journal of Constitutional Law 1008, 1024.

${ }^{55}$ Tom Hickman, Public Law After the Human Rights Act (Hart, Oxford/Portland, Oregon, 2010) 2.
} 
analysis of the relationship between the FCC and the Strasbourg court lends support to my claim. As she puts it, 'It is not contemplated in the German constitutional context that representatives from other constitutional branches than the judiciary criticise or even defy a judicial decision. The ECtHR belongs to the judiciary. Therefore the FCC is the only organ with the authority to voice such criticism. ${ }^{56}$

The central claim of this subsection is that the finely calibrated structure of the HRA, which invites both courts and Parliament to develop their own interpretation of human rights and makes reasonable rights disagreement an integral feature of institutional design, fits uneasily with the supervision of the Strasbourg court. The supervision of the Strasbourg court gives rise to either a practical or a conceptual problem, depending on what status one attributes to the interpretation of the Court.

To spell out this point, let me introduce a distinction between the authoritative and authentic status of a legal interpretation. ${ }^{57}$ If we treat someone's interpretation as the authoritative one, we have a reason to act upon this interpretation from the moment that the authoritative decision is made. (An authoritative decision is a prospective reason to act in a certain way.) However, if we do not have a reason to believe that the Court's interpretation is the correct one, we do not have a reason to feel ashamed if our interpretation differed or still differs from the authoritative one. If the Strasbourg court's interpretation of the Convention has authoritative status, the problem this creates for weak judicial review is a practical one. If a member state of the Council of Europe wants to avoid the unfavourable decisions of the ECtHR, its institutions should, on the one hand, follow Strasbourg case law where there is such a case law, and on the other hand, try to predict how the Strasbourg court will decide where there is not such a case law. There is no practical point in developing one's own interpretation of a human right if, for all intents and purposes, what matters is how the supervisory institution interprets the human right in question. ${ }^{58}$

It is a widely held opinion that a government should feel ashamed or embarrassed if the Strasbourg court finds that it has violated a human right. Avoiding international embarrassment was arguably a major consideration, for instance, for enacting the HRA. ${ }^{59} \mathrm{My}$ contention is that this reaction is adequate only if we believe that the Strasbourg court's

\footnotetext{
56 Rackow, 'From Conflict to Cooperation: The Relationship Between Karlsruhe and Strasbourg' in Ziegler, Wicks and Hodson (n 45) 387.

${ }^{57}$ I am aware that this is not the conventional meaning of authentic interpretation.

58 The three qualifications I made about the primacy of the Strasbourg court above also apply to this claim.

${ }^{59}$ Kavanagh (n 54) 1024.
} 
interpretation is the correct one and the government, as any other reasonable interpreter of the ECHR, should have reached the same conclusion. To put it slightly differently, this view considers the interpretation of the Strasbourg court not only as the authoritative but also the authentic one. If someone treats another person's or institution's view as authentic, they have a reason to believe that the said interpretation is the correct one and that their own contrary interpretation has been wrong all along. In that case, the problem at hand is not a practical but a conceptual one. The idea of authentic interpretation denies the very possibility of reasonable rights disagreements, as it implies that the other interpretations do not have the same epistemic status. Attributing authentic status to the decisions of the Strasbourg court is incompatible with the assumption (the equal epistemic status of courts and Parliament) that makes the Commonwealth model of judicial review attractive to many of its proponents.

\section{The argument from political malfunctions}

The strongest argument for domestic constitutional review is not that courts have an epistemic advantage over legislative bodies to make good decisions, but rather that the members of the two institutions are differently motivated and the courts' insulation from the political process is a major advantage when it comes to the specification of human rights. ${ }^{60}$ By being insulated from the political process, so the argument goes, courts can correct the malfunctions of the political system. For instance, courts are thought to be more willing to protect the interests of unpopular and vulnerable minorities than the elected branches of the government. The logic of this argument can be easily extended to the international context. ${ }^{61}$

Although the independence of the judiciary insulates it from the political process, this insulation is far from perfect. The malfunctions of the political system can become so pervasive that even the judiciary is affected by them. According to Justice John Hedigan, this is what happened in Europe in the interwar period. He claims that the main reason for the establishment of the European human rights regime was that 'institutions at the national level had failed demonstrably'. ${ }^{62}$ The recent attacks on the independence of the Polish judiciary remind us that the aforementioned threat has not ceased to exist. If this is the case, an international court that is not exposed to the pressures of domestic politics might be a more

\footnotetext{
${ }^{60}$ R Dworkin, Taking Rights Seriously (Duckworth, London, 1977) 85.

${ }^{61}$ However, some commentators jump from the need to protect minority rights directly to the legitimacy of ECtHR without even trying to establish that domestic courts are unable to fulfil this function. See Benvenisti (n 37) $848-850$.

62 J Hedigan, 'The European Court of Human Rights: Yesterday, Today and Tomorrow' (2011) 12 German Law Journal 1716, 1716.
} 
reliable protector of human rights than its domestic counterparts. In addition, international human rights courts act not only as external checks on domestic political institutions but can also shape the domestic political landscape by mobilising civil society actors and opposition parties, strengthening the position of domestic courts that are under political pressure and serving as a point of reference for domestic political discourse.

Although the proponents of the European human rights regime have a valid point, they both overgeneralise this argument and lift it out of the context of the justificatory equation. As a general claim, Justice Hedigan's statement is demonstrably false. After World War I, there existed altogether 29 democracies, 22 of them in Europe. ${ }^{63}$ Justice Hedigan is right to point out that there was a considerable backlash in the process of democratisation in the interwar period: out of these 29 countries, 11, including 10 European ones, turned into dictatorships. However, there were 16 countries, including 12 European ones in which democratic development was uninterrupted or was interrupted only provisionally and by external occupation. The breakdown of national political institutions, therefore, was hardly a general phenomenon.

Let us turn now from explanation to justification. Although it is true that there is a certain risk of political malfunctions in each political system, the gravity of this risk varies from one country to another. Even without extensive empirical analysis, it seems safe to assume that this is much smaller in consolidated democracies with a strong tradition of judicial independence and democratic political culture than in new democracies with fragile institutions and an autocratic political culture. Addressing political malfunctions provides each state with $a$ valid reason for endorsing the authority of an international human rights court, but the strength of this argument is contingent on the robustness of the political system in question. The weaker the argument from political malfunctions is, the easier the argument can be overridden by sovereignty-related and epistemic considerations.

Of the 47 member states of the Council of Europe, the Economist Intelligence Unit's democracy report classifies 14 as full democracies, 18 as flawed democracies, nine as hybrid regimes and two as authoritarian states. ${ }^{64}$ (Andorra, Liechtenstein, Monaco and San Marino are not on the EIU's democracy index.) As far as the 14 full democracies are concerned, in 2017, altogether 44 judgments of the ECtHR found at least one violation of the Convention. ${ }^{65}$

\footnotetext{
${ }^{63}$ The analysis of the present paragraph relies on the dataset of Boix, Miller and Rosato, 'A Complete Data Set of Political Regimes, 1800-2007’ (2013) 46 Comparative Political Studies 1523.

${ }^{64}$ Available at: <eiu.com/topic/democracy-index>

${ }^{65}$ The data about the number of violations are available at: 〈echr.coe.int $\rangle$.
} 
By contrast, Russia, one of the two authoritarian states, generated alone 293 judgments that found at least one violation.

There is a clear correlation between the robustness of the political system and the gravity of human rights violations. In full democracies, the number of judgments that found at least one violation is 0.16 for one million inhabitants. The respective number is 0.95 in flawed democracies, 1.59 in hybrid regimes and 2.06 in authoritarian regimes. The robustness of political institutions is also the most reliable indicator of whether a state will comply with the unfavourable decisions of the Court. ${ }^{66}$ If the rationale for an international human rights court is the correction of political malfunctions, different member states simply have very different needs.

Some commentators have noticed that the critique of the ECtHR has created an odd alliance between the United Kingdom and Russia. ${ }^{67}$ When someone raises the possibility that the United Kingdom could withdraw from the ECHR, commentators routinely point out that with that move, the UK would align itself with Belarus and would become a pariah state. ${ }^{68}$ Although at first sight, these parallels seem indeed odd and striking, the argument from political malfunctions is able to provide a plausible explanation for them.

Andrew Moravcsik has argued in an excellent paper that the differences between consolidated democracies, new democracies, and authoritarian regimes can account for how different countries acted during the negotiating history of the ECHR. ${ }^{69}$ I suggest here that the explanatory power of his theory is not limited to the negotiating period of the ECHR but also applies, to some extent, to contemporary attitudes towards the ECtHR.

A.) Authoritative governments do not care much about human rights, they do not want any restrictions on their power and, therefore, have a strong motivation to ignore the decisions of human rights courts or minimise their impact. Since it is unlikely that they will lose their power, they do not have incentives to create insurance mechanisms for the period when they are in opposition. ${ }^{70}$

\footnotetext{
${ }^{66} \mathrm{C}$ Hillebrecht, 'The Power of Human Rights Tribunals: Compliance with the European Court of Human Rights and Domestic Policy Change' (2014) 20 European Journal of International Relations 1100, 1114.

${ }^{67}$ Madsen (n 17) 169-70. It is worth mentioning that some of the Russian criticisms come from the Constitutional Court of Russia. See A Burkov: 'How to improve the results of a reluctant player: The case of Russia and the European Convention on Human Rights' in Flogaitis et al (n 8)

68 'Britain could become Belarus if it abandons human rights legislation, warns Attorney General' The

Telegraph, 9 October, 2012.

${ }^{69}$ Moravcsik (n 16).

${ }^{70}$ Ginsburg, Judicial Review in New Democracies: Constitutional Courts in Asian Cases (CUP, Cambridge, 2003) 25.
} 
B.) Consolidated democracies might be as critical of strong human rights courts as authoritarian regimes. ${ }^{71}$ However, my contention is that unlike authoritarian regimes, they have not only an understandable motive but also a valid justificatory reason to be less enthusiastic about such courts. Since they have robust political institutions and a strong tradition of judicial independence, they have much less reason to believe that their domestic courts will cease to function properly and will become unable to protect human rights on their own. Although we cannot eliminate this possibility altogether, we should not assess this argument in isolation, but as part of the justificatory equation. It is not unjustified to believe that having an insurance mechanism in the form of an international court for the unlikely event that the domestic judiciary becomes dysfunctional, does not compensate for the certain and immediate costs of the transfer of authority in procedural and epistemic terms.

The logic of the above argument applies to all stable democracies and is not limited to the United Kingdom. However, just as the epistemic argument against international human rights adjudication, the argument from political malfunctions also gets a special twist in light of the UK's constitutional traditions. The idea of 'locking in' or putting some policy decisions beyond the reach of ordinary majorities fits well with the constitutional traditions of most European countries. All other European states have entrenched constitutions - that is, in these states, amending the constitution requires a more burdensome process than ordinary legislation. In addition, no fewer than 14 European constitutions have so-called 'eternity clauses' that make certain provisions or principles of their respective constitutions unamendable. By contrast, the very idea of entrenchment is at odds with the traditional understanding of parliamentary supremacy, the most fundamental principle of the British constitution.

C.) Finally, new democracies that are committed to the idea of human rights have more reasons to believe that they need an external institution as an insurance in case there was a backlash in the process of democratisation. The politicians of the young democracies of Central and Eastern Europe, for instance, had good reasons to seek such an insurance policy after the collapse of the socialist regime. Since they had no experience with the peaceful change of government, by putting some issues beyond the domestic political process, they could ensure that at least some decisions could not be changed even if they lost their power.

\footnotetext{
${ }^{71}$ However, their attitude to compliance is fundamentally different. For a comparison between Russia and the UK, see C Hillebrecht, 'Implementing International Human Rights Law at Home: Domestic Politics and the European Court of Human Rights’ (2012) 13 Human Rights Review 279.
} 
As Moravcsik argues: 'Only where democracy is established but undemocratic groups (military officers, communists, fascists, and religious fundamentalists, for example) pose a real threat to its future is the reduction of political uncertainty likely to outweigh the inconvenience of supranational adjudication. ${ }^{72}$

\section{The argument from reputation}

The question of how reputational concerns motivate states is discussed extensively in the theory of international law and international relations. ${ }^{73}$ Although most of these studies focus on how a country's reputational interests influence its compliance with international law, many of the insights of this literature are relevant beyond the question of compliance.

Reputational interests can both explain and justify why a state ratifies an international treaty in the first place. From this more general perspective, compliance with international commitments is only one factor in the overall reputation of a country.

Each country wants to be respected by others and secure a certain status or standing within the international community. Or to be more precise, each country wants to portray a certain image about itself and wants to be not simply respected but respected as a polity of a certain kind. This image is constituted partly by values the country identifies with. Other polities that share the same values serve as a reference group for the country in question. However, it is important to note that the image the country wants to portray does not necessarily coincide with the one that makes a country appealing to the international community.

For many countries, the liberal conception of human rights is an integral part of the image they want to portray. They want to be recognised as a polity that respects those rights. A good track record of human rights protection is not only a source of self-esteem but also earns them the recognition of other states.

The reputation of a country is made up of different factors, some of which have nothing to do with formal institutions. But perhaps it is not a coincidence that the countries

\footnotetext{
72 Moravcsik (n 16) 229.

73 GW Downs and MA Jones, 'Reputation, Compliance, and International Law' (2002) 31 Journal of Legal Studies 95; AT Guzman, 'A Compliance-Based Theory of International Law' (2002) 90 California Law Review 1823; AT Guzman, 'Reputation and International Law Symposium: The Limits of International Law' (2005) 34 Georgia Journal of International and Comparative Law 379; AT Guzman, How International Law Works: A Rational Choice Theory (2010); Helfer and Slaughter (n 4); RO Keohane, 'International Relations and International Law: Two Optics' (1997) 38 Harvard International Law Journal 487.
} 
with the strongest overall reputation are exactly the ones that are the most democratic. In the previous section, I have already alluded to the Economist Intelligence Unit that publishes every year its report on the democratic performance of states. ${ }^{74}$ The Reputation Institute is an organisation that monitors the 55 biggest economies and ranks the 'brand value' of those countries. Unsurprisingly, the top ten lists of the two rankings are almost identical. ${ }^{75} \mathrm{My}$ contention is that the argument concerning a state's reputation sheds further light on why different countries have different attitudes towards the European human rights regime.

A.) New democracies that aspire to be seen as countries that respect human rights consider consolidated democracies as a reference group. Since they aspire to become stable democracies, they feel cognitive and social pressure to respect human rights. The cognitive pressure comes from the fact that they want to minimise the dissonance between their actions and the image they want to portray. ${ }^{76}$ But they also want to avoid criticism, naming and shaming, and want to get positive feedback and public approval from the members of their reference group. The mechanism when someone conforms to the expectations and behaviour of others without fully internalising the values that create those expectations is called acculturation. ${ }^{77}$ Acculturation is different from persuasion, as it implies only conformity to, but not necessarily belief in, the importance of those values. But acculturation is also different from tactical concession as it derives not from utilitarian calculation but from the identification with a certain reference group. ${ }^{78}$

Acculturation is probably one of the most important mechanisms that are responsible for isomorphism. ${ }^{79}$ In the present context, isomorphism means that countries with very different traditions and demands create increasingly similar legal and political institutions. Isomorphism is a well-documented phenomenon in constitutional design and in the protection of human rights. ${ }^{80}$ The ECtHR has an important role in that process, as the Court is both a beneficiary and an agent of acculturation (although the doctrine of the margin of appreciation mitigates the homogenising effect of the Court's jurisprudence.) Today, subjecting national

\footnotetext{
74 Available at: <eiu.com/topic/democracy-index>.

${ }^{75}$ Available at <reputationinstitute.com/research/Country-RepTrak.aspx >. (Iceland is second on the EIU's ranking, but it is not monitored by the Reputation Institute.)

${ }^{76}$ R Goodman and G Jinks, Socializing States: Promoting Human Rights through International Law (2013) 27.

${ }^{77}$ Ibid, 25-32.

78 Ibid, 26-32.

79 PJ DiMaggio and WW Powell, 'The Iron Cage Revisited: Institutional Isomorphism and Collective Rationality in Organizational Fields,' (1983) 48 American Sociological Review 147.

${ }^{80}$ DS Law and M Versteeg, 'The Evolution and Ideology of Global Constitutionalism' (2011) 99 California Law Review 1163.
} 
legal systems to the authority of the ECtHR is seen as the norm in Europe. The normal way of doing things creates expectations, and deviation from the normal course of action attracts criticism and is detrimental to the reputation of the deviant state (for example, see the reference above to Belarus as a pariah state).

The new democracies of Central and Eastern Europe, again, provide a good illustration of my point. Many of them ratified the ECHR as soon as they could after the collapse of their socialist regimes and created domestic constitutional courts. We can safely assume that not all members of the new elite of these countries became the honest proponents of human rights. However, they wanted their country to belong to the family of liberal democracies, identified with the members of their reference group, and ratifying the ECHR made their commitments to human rights more credible. ${ }^{81}$ As Guzman says, 'the [reputational] theory predicts, then, that states with more fragile reputations will make greater efforts to comply with international law than would a similarly situated state with a stronger reputation. $^{\text {, }} 2$

There is empirical evidence that new democracies sent judges to the ECtHR who were, on average, more activist than the ones sent by consolidated democracies, to prove that they were good students. ${ }^{83}$ In addition, judges from former socialist countries were harsher on other socialist countries than they were on countries without socialist heritage. ${ }^{84}$ The credible commitment to the protection of human rights certainly improved the reputation of these countries. For the same reason, their reputation would be seriously damaged if they left the ECHR. But the Court has also contributed to how the citizens of these countries judged the reputation of their respective countries. The judgements of the Court have served as a shared point of reference by which the participants of the domestic political discourse assessed and criticised the actions of others and justified their own actions.

B.) There are some member states, such as Russia, Turkey, and Hungary that have become vocal critics of the Strasbourg court. Of course, these countries also want to be respected but want to be respected on their own terms, and not as liberal democracies. It is telling, for example, that of all the countries that are monitored by the Reputation Institute, the biggest gap between the external reputation of the country and its self-image reputation

\footnotetext{
${ }^{81}$ However, it has to be mentioned that material inducement was also an important motivating factor for many countries since ratifying the ECHR was a precondition of EU membership.

82 Guzman, How International Law Works: A Rational Choice Theory (n 73) 91.

${ }^{83}$ E Voeten, 'Politics, Judicial Behaviour, and Institutional Design' in Christoffersen and Madsen (n 4) 67-9.

84 Ibid, 73.
} 
exists in Russia. While external respondents see Russia's reputation pronouncedly weak (51st out of 55), Russians put their own country's reputation at the very top of the list (2nd out of $55)$.

These countries no longer identify with the core values of liberal democracies and do not treat them as a reference group. In Russia, there is a long intellectual tradition of defining Russian identity in contrast to the West. ${ }^{85}$ Viktor Orbán, Hungary’s prime minister, pursues self-professedly illiberal policies and has made 'Brussels' one of the targets of his criticism. ${ }^{86}$ Although these countries do not necessarily reject the general idea of human rights, they give human rights an idiosyncratic interpretation. They increasingly brand the Strasbourg court as part of a hostile liberal order that misunderstands and mistreats them. Orbán regularly makes derogatory remarks on human rights and considers them idealist theoretical constructions that are out of touch with the political reality. ${ }^{87}$ Both Russia and Hungary are hostile to human rights organisations, and stigmatise them as foreign-funded institutions, with the implication that they support foreign interests.

Since these countries do not aspire to be seen as liberal democracies, there is no cognitive pressure on them to act as one of them. External criticism is considered, by definition, as hostile to the traditions, the values or the independence of the political community. Their narrative is replete with references to respect, ${ }^{88}$ pride $^{89}$ and honour, ${ }^{90}$ suggesting that drawing the attention to their human rights failures is not a form of rational criticism but an attack on the distinctive way of life, or the dignity of the nation. At the time of writing, the European Parliament has voted to pursue a disciplinary action against Hungary over alleged breaches of the EU's core values. Speaking to the members of the European

\footnotetext{
${ }^{85}$ For recent surveys on the history of Russian identity, see PJS Duncan, 'Contemporary Russian Identity Between East and West' (2005) 48 The Historical Journal 277; A Likhacheva, I Makarov and E Makarova, 'Post-Soviet Russian Identity and Its Influence on European-Russian Relations' (2015) 3 European Journal of Futures Research 4; Riasanovsky, Russian Identities : A Historical Survey (OUP, Oxford, 2005).

86 'Prime Minister Viktor Orbán's Speech at the 25th Bálványos Summer Free University and Student Camp'. Available at: <kormany.hu/en/the-prime-minister/the-prime-minister-s-speeches/prime-minister-viktor-orban-sspeech-at-the-25th-balvanyos-summer-free-university-and-student-camp>.

${ }^{87}$ Available at: <miniszterelnok.hu/orban-viktor-beszede-a-hatarvadaszok-eskutetelen-2〉 .

${ }^{88}$ Responding to the critiques of the recent attack on the judiciary, Poland's Justice Minister, Zbigniew Ziobro's reply is replete with references to respect ("We expect and demand respect", for example). 'EU-Poland row gets personal as war of words heats up' Euronews, 27 July 2017. Available at: <euronews.com/2017/07/27/eupoland-row-gets-personal-as-war-of-words-heats-up >

89 As of writing this article, Hungarian streets are full of posters declaring that "Hungary is a proud and strong European nation."

90 For using honour as an analytical category and applying it to Russian foreign policy, see AP Tsygankov, Russia and the West from Alexander to Putin. Honor in International Relations (CUP, Cambridge, 2012).
} 
Parliament, Orbán claimed that 'You are not going to condemn a government but a country as well as a nation. You are going to denounce Hungary that has been a member of the family of Christian nations for a thousand years. ${ }^{, 91}$

In these countries, the Court's jurisprudence has never served or no longer serves as a shared point of reference in domestic political discourse. Although civil society organisations and opposition parties might refer to the decisions of the Court, these critiques do not appeal to the whole political community, as most supporters of the government do not consider these decisions as legitimate standards by which the government should be judged.

C.) Finally, the respect for human rights plays a central role in the self-image of consolidated democracies and this is one of the reasons that these countries have a strong reputation. However, their reputation as human rights compliant countries builds primarily on their own track record and does not rely so much on the stamp of approval from an international court. I am not saying that withdrawing from the ECHR would not negatively affect the reputation of these states. It certainly would. Regardless of the actual standard of human rights protection, the perception would be that they do not take human rights seriously enough. Perhaps even more importantly, mature democracies could also be criticised for sending the wrong message to those states that would indeed profit from the supervision of the Strasbourg court. My point is that their reputation would suffer much less than that of new democracies since they could more credibly claim that their system of human rights protection is robust enough even without the support of the Strasbourg court.

The United Kingdom is often seen both by its citizens and external observers as the cradle of parliamentary democracy. Westminster is often called - inaccurately - the mother of parliaments. ${ }^{92}$ 'Teaching grandmothers to suck egg', the idiom used by Lord Hoffmann to characterise the relationship between the ECtHR and UK courts, makes a reference to the long tradition of the rule of law and judicial independence in the UK. ${ }^{93}$ Although Lord Hoffmann's position might seem complacent or even arrogant to some readers, this is not a reason to disagree with the more modest claim that the UK belongs to the group of those countries that could credibly rely on their own democratic credentials. ${ }^{94}$

\footnotetext{
91 'Orbán defiant as EU parliament considers sanctions on Hungary’ Guardian, 11 September 2018.

92 C Bryant, Parliament: The Biography (Volume I - Ancestral Voices) (Transworld, London, 2015) at 16-17.

93 Lord Hoffmann (n 33) 417.

${ }^{94}$ Luebbe-Wolff (n 20) 97-8. Of course, Brexit puts the above argument in a new and very different international context. However, at present, it would be premature to speculate on the potential effects of Brexit on the protection of human rights in the UK.
} 


\section{The arguments from collective responsibility and collective security}

As human beings, we should care about how other human beings are treated by their respective governments. The universal scope of human rights gives rise to a general responsibility and, therefore, we should demand of our state, let us call it country $A$, to promote human rights worldwide. However, it does not follow without further arguments that the best way to act upon this collective responsibility is to demand a uniform interpretation of human rights of other countries, including country $B$. Human rights do not simply exist, waiting to be enforced, but have to be interpreted and specified. As they have more than one reasonable interpretation, the fact of reasonable rights disagreement has to be factored into how we act upon our collective responsibility. Even if country $A$ cares about the human rights of the citizens of country $B$, if there is a reasonable rights disagreement between country $A$ and country $B$, the best course of action for country $A$ regarding country $B$ is giving privileged, but not conclusive, status to how the citizens of country $B$ themselves interpret human rights. (It is important to note that when I attribute a particular interpretation of a human right to country $B$, I am not assuming that all the citizens of country $B$ share the same view. Instead, I refer to the interpretation of a human right that is reflected in the authoritative decisions and institutional practices of the state.) This is an implication of the more general idea of dignity, emphasised by Waldron: 'Law, we can say, is a mode of governance that acknowledges that people likely have a view or perspective of their own to present on the application of a social norm to their conduct. Applying a norm to a human individual is not like deciding what to do about a rabid animal or a dilapidated house. It involves paying attention to a point of view. In this way it embodies a crucial dignitarian idea-respecting the dignity of those to whom the norms are applied as beings capable of explaining themselves.' 95

The citizens of country $B$ should be treated not as the passive beneficiaries of enlightened human rights decisions but as people who have an independent perspective on what human rights require. Therefore, as I claimed above, country $A$ can err in two directions with regard to country $B$. Although it is problematic if country $B$ can get away with the manifestly unreasonable interpretations of human rights, it is equally problematic if country $B$ cannot pursue those reasonable interpretations of the same rights that are preferred by their

\footnotetext{
95 J Waldron, Dignity, Rank, and Rights (The Berkeley Tanner Lectures) (OUP, Oxford, 2012) 54.
} 
citizens. The best course of action for country $A$ with regard to country $B$ is, therefore, contingent on the balance of these two considerations.

Nevertheless, where there is a strong case that country $B$ would profit from joining an international human rights regime, provided that other states, including country $A$, do the same, $A$ has a prima facie reason to join the same regime. I will call this the argument from collective responsibility.

Although country $A$ might honestly care about the state of human rights in country $B$, I am not sure that the argument from collective responsibility is strong enough to compensate for the sovereignty costs of such a decision and the epistemic suboptimality of international human rights mechanisms.

But we can also appeal to the self-interest of country $A$ to join an international human rights regime. It might be in country $A$ 's self-interest to promote human rights in country $B$, if country $B$ 's human rights violations impose externalities on country $A$. Let me call this the argument from collective security. As Luebbe-Wolff says, 'In the long run, it is in our own interest to keep that system effective, because, in a globalized world, the general lawlessness and moral corruption that necessarily go along with contempt for human rights are likely to cross borders like contagious diseases. ${ }^{96}$

We should not forget that after World War II, one of the reasons for creating the European human rights mechanism was to prevent the possibility of totalitarian takeovers. As Michael O'Boyle explains, 'this concept [the idea of collective guarantee] is the cornerstone of the Convention system. Without it the treaty would have little sense. The idea of the collective guarantee of rights is essentially a reciprocal agreement by the Contracting Parties embodied in the Convention and its machinery of supervision, that each of them and their peoples has an enduring interest in how fundamental rights are being protected in other State Parties.' 97

Once again, the proponents of the ECtHR certainly have a valid point, but they often write as if the consideration of collective security was a kind of master argument that evidently overrides all other considerations. ${ }^{98}$ However, this is not the case: the strength of this argument is contingent on many factors and varies over time. It certainly depends on the nature, the likelihood and the proximity of the danger to be avoided. When the ECHR was adopted, it was primarily meant to prevent the countries of Western Europe from sliding into

\footnotetext{
${ }^{96}$ Luebbe-Wolff (n 20) 98.

97 O’Boyle (n 6) 1867.

98 Spano (n 5) 493.
} 
totalitarianism. The Court was supposed to operate as a sensitive alarm bell that signals the rise of totalitarianism. The emergence of a totalitarian regime in the middle of Europe would have certainly and directly affected every European nation; therefore, one could plausibly appeal to the self-interest of each country to give up part of its authority.

However, as Moravcsik points out, even this possibility did not prove to be a decisive factor in the calculations of most countries. ${ }^{99}$ For instance, although in the light of the experiences of World War II the relationship between the stability of German democracy and the security of France and the UK should have been quite clear, it did not give France sufficient incentive to ratify the Convention or the UK to accept the jurisdiction of the Court. By the time France ratified the ECHR (1974) and the UK accepted the jurisdiction of the Court (1966), West Germany had become a stable democracy and the chances of a communist takeover in France had significantly decreased.

Since the ECHR came into force, the political landscape has undergone a considerable change. Although there are worrying populist and authoritarian tendencies in many European states, at present, all West European countries are, using the EIU's terminology, either full or flawed democracies - all the countries that are classified by the EIU as hybrid or authoritarian regimes can be found on the periphery of Europe. Although the authoritarian tendencies of these countries should be taken seriously, the rise of populism in Western Europe has primarily internal causes and cannot be explained by the appeal of the Turkish or Russian models. The situation is slightly different when the erosion of democracy takes place in a member state of the European Union. Since many decisions in the Council of the European Union require only a qualified majority, the democratic backlash of some member states imposes a direct externality for stable democracies. ${ }^{100}$

Even if my general risk-assessment is completely wrong, we should keep in mind that the risk factor is only one part of the equation. Both the argument from collective responsibility and the argument from collective security assume that states can be effectively influenced and socialised by international human rights regimes. ${ }^{101}$ If the authoritative tendencies in country $B$ pose a real danger for country $A$, a court can mitigate this danger only if it is able to effectively influence country $B$. I contend that the strength of both arguments

\footnotetext{
${ }^{99}$ Moravcsik (n 16) 237.

${ }^{100}$ I am grateful to one of the anonymous reviewers for drawing my attention to this point.

${ }^{101}$ In addition, the proponents of the ECtHR should also establish that we need a court to influence the behaviour of member states and 'less drastic means' are not available.
} 
relies on the chances of successful acculturation.

The European human rights regime can identify systemic human rights violations but cannot coerce states into cooperation. 'Good faith participants in such regimes are generally unwilling or unable to shoulder the enforcement costs necessary to coerce recalcitrant states to comply with human rights norms. ${ }^{102}$ As the growing number of cases pending before the Committee of Ministers indicates, 'partial compliance appears increasingly the norm in both Western and Eastern Europe.' 103

States with authoritarian tendencies might pay lip service to human rights and comply with the individual decisions of the ECtHR; however, they will try to minimise the effects of such decisions and limit the authority of the Court to what is called in the literature 'narrow authority' ${ }^{104}$ Although providing remedies to individual victims of human rights violations is important in its own right, the ECtHR is simply not in the position to give effective remedy to 839 million people without the contribution of the member states. ${ }^{105}$ Therefore, the success of the European human rights regime depends on whether the behaviour of non-cooperating states can be changed.

The precondition of acculturation is that countries without long democratic tradition consider liberal democracies as a reference group and identify with core liberal values. However, some countries, such as Russia, Turkey and Hungary, aspire to provide an illiberal alternative to constitutional democracies rather than to become one of them. Without the resources and willingness to coerce the states that do not comply with human rights standards and without the preconditions of successful socialisation, neither the argument from collective responsibility nor the argument from collective security is convincing. If my analysis is correct, today the argument from collective security offers very little to consolidated democracies: it is debatable whether the human rights violations of other European countries impose serious externalities on them, and even if that is the case, they have little chance to socialise non-compliant states.

\section{Conclusion}

I have argued in the present paper that each country has both valid procedural and epistemic

\footnotetext{
102 Goodman and Jinks (n 12) 629.

103 Madsen (n 17) 173.

${ }^{104}$ KJ Alter, LR Helfer and MR Madsen, 'How Context Shapes the Authority of International Courts' (2016) 79 Law and Contemporary Problems 1, 10.

${ }^{105}$ Greer and Wildhaber (n 4) 665; Hillebrecht (n 71) 283-4.
} 
reasons to give pre-eminence to their domestic courts in the specification of human rights. Although these reasons must be balanced against other arguments (the argument form political malfuncions, the argument from reputation, the argument from collective responsibility and security, for example), the strength of the latter arguments is contingent on the robustness of democratic institutions. I am not claiming here that these considerations can never tip the balance of arguments in favour of a strong transnational human rights regime for some countries. However, I submit that the balance of arguments is very different in the case of stable democracies with a strong tradition of judicial independence and a reasonably good track record of human rights protection, such as the United Kingdom. I believe that they have good reasons to remain part of the European human rights regime only if the ECtHR applies a consistently deferential approach with regard to them and does not replace the reasonable human rights interpretations of the domestic courts of those democracies with its own reasonable views. Even though the ECtHR currently gives more leeway to national courts than before, the Court's activity still goes well beyond policing the limits of reasonable interpretations of human rights.

Although these considerations are not unique to the United Kingdom, there are some further reasons that explain or justify (or both) why the UK is especially critical of the Strasbourg court. Starting with the most obvious point, the idea of an overarching European demos as the location of final political authority has always been glaringly unattractive in the UK. That is one factor that explains why the UK is more critical of the Court than many other stable democracies. Second, the idea of putting certain policy decisions beyond the ordinary political process (a method often used to address political malfunctions) is also foreign to the British constitutional tradition that is built on the idea of parliamentary supremacy. Finally, the supervision of the Strasbourg court fits uneasily with a domestic system of human rights protection that gives the final say on what human rights require to the legislature, and is, arguably, predicated on the idea that legislators and courts are epistemic equals when it comes to the specification of human rights.

\section{Acknowledgements}

The author would like to thank Paul Beaumont, Richard Bellamy, Mátyás Bódig, Andreas Føllesdal, Gábor Halmai, András Jakab and Zsolt Körtvélyesi for valuable comments, discussions and suggestions. 